\title{
4. Facing the Warrior: An Ethnographic Montage on Post-9/11 Warriorisation of Danish Military Professions
}

Thomas Randrup Pedersen

The best subjects of modernist ethnography are those which have been heavily represented, narrated, and made mythic by the conventions of previous discourse.

George Marcus (1990, P. 7)

"Welcome to the warrior club."

This was the message Sergeant (Sgt) Eik texted me a few years back on receiving the news that I had taken up a position in the Danish Armed Forces. ${ }^{1}$ I had come to know Eik, who serves in the fighting arms of the Danish Army, as one of my informants during my doctoral studies. His message put a smile on my face. Not only did it seem to indicate that I had become a card-carrying member of a military organisation, even a league of warriors, in spite of my status as a civilian (and not a very warlike one, at that); the message constituted yet another instance of a phenomenon that has frequently sparked my ethnographic wonder: the "warriorisation" I identify, and describe below, as the association of mili-

1 I have changed the names of my informants to shield their identities. 
tary professions with the figure of the warrior. Interestingly, it is a phenomenon that has become increasingly noticeable among both insiders and outsiders to the armed forces in post-9/11 Denmark (see also Pedersen, 2019c).

How do we explain the rising popularity of the notion of the warrior across civilian and military spheres in early 21 st century Denmark? Why is warriorhood increasingly ascribed to, and claimed by, members and ex-members of the Danish Armed Forces, supplementing, even replacing, time-honoured terms such as "officer," "soldier," and "veteran"? What is at stake? What is in a name? What does the change of language tell us about military professions in transformation and changing relations between armed forces and society?

This chapter investigates military professions and civil-military relations through an anthropological analysis of the cultural figure of the warrior. Conceiving "warrior" to be a professional identity and thereby as a constructed, contested, and contextual notion (Jenkins, 2014), I explore what warrior identities "do" to military professions and civil-military relations across different contexts, be that instrumentally in terms of expertise and corporateness (Huntington, 1957) or existentially in terms of senses of agency (Jackson, 2013; see also Coker, 2007). I further examine how warrior identities are "done" not merely discursively, but also performatively (Goffman, 1959; Jenkins, 2014; see also West \& Zimmerman, 1987). By implication, I shed light on those "doing" warrior identities, either in terms of institutional subject formation, or in terms of intersubjective fashioning of self and other (Foucault, 1977; Rapport, 2003; Jenkins, 2014). Finally, I scrutinise why Denmark has witnessed an emergence of warrior identities within the past decade, especially.

Denmark is not the only country where warriorisation is on the rise. The phenomenon can also be observed in the United States and in the United Kingdom. In fact, Gibson (1994) has demonstrated that a widespread warriorisation of American (popular) culture emerged as early as in the 1980s in response to the American failure in Vietnam. Then, the "new warrior hero was only occasionally portrayed as a member of a conventional military or law enforcement unit," (Gibson, 1994, p. 9). In post-9/11 America, however, warriorisation has not merely expanded into military cultures, it has, indeed, become increasingly institutionalised, as evidenced by the U.S. Army's adoption of its "Warrior Ethos" in 2003 (Loeb, 2003) and by its "Warriors Wanted" and "What's Your Warrior?" recruitment campaigns launched in 2018 and 2019, respectively (Cox, 2018; Rempfer, 2019). In both America and Britain, the growing warriorisation of military professions has recently sparked debates over the ethical, historical, and social plausibility of referring to "our troops" as "warriors" (Angry Staff Officer, 2016; Ricks, 2016; Beehner, 2019; Noordally, 2020; W., 2020; Matthew, 
2020). In Denmark such debates are yet to be seen in earnest, and I hope the present chapter will help stimulate them.

As for the question of why Danish military professions have been increasingly warriorised in the post-9/11 years, two answers seem plausible. First, given that the United States and the United Kingdom constitute Denmark's closest military coalition partners in the "war on terror," one could argue that warriorisation in the Danish case is a matter of Americanisation/Anglicisation (see Høiback, this volume). Second, given that Denmark broke with a long history of pacifism/ defeatism with the deployment of Danish troops to combat missions in the wars in Afghanistan (2002-2014) and Iraq (2003-2011), one could argue that warriorisation in Denmark is a question of reviving a "warrior spirit" - that is, the military value of killing and risking getting killed, which had faded away during "peacetime" (see Holsting, this volume). While both arguments have their merits on macro-historical levels, they do not tell us much about present-day warriorisation on either meso- or micro-historical/sociological levels. Accordingly, I pursue an alternative methodological approach here. With the aim of drawing a multi-perspectival and multifaceted portrait of the cultural figure of the warrior, I adopt the technique of ethnographic montage to present my empirical material and my analytical reflections in a relatively discontinuous and subject-decentred manner (Marcus, 1990). This potentially makes contradictory, even conflicting, "gaps" visible between different warrior identities - or between what I describe as different "faces of the warrior."

In an attempt not merely to represent the world but to re-textualize it in an unstable and incomplete form, I draw inspiration from the cinematic trope of montage. Initially, the montage method was conceptualised by George Marcus (1990) as an alternative approach to ethnographic writing - a modernist approach which disrupts the coherent narrative of much social science writing (Marcus, 1990; Willerslev \& Suhr, 2013). Broadly speaking, montage "simply implies the joining together of different elements in a variety of combinations, repetitions, and overlaps" (Willerslev \& Suhr, 2013, p. 1). Crucially, the result of bringing disparate elements together in a montage is, as Willerslev and Suhr argue, never "simply the sum of the single components. Something extra, a surplus or an excess, is always produced." Conceiving this "extra" as opening a "gap" through which "the invisible becomes present as an absence of visibility" (Willerslev \& Suhr, 2013, p.5) in terms of fuzziness, dissonance or incongruence, montage allows for amplification of the invisible, for highlighting fragmentary complexities and co-existing contradictions of social reality (Marcus, 1990; Willerslev \& Suhr, 2013).

The military professions I study in this chapter are those of the officer corps and the enlisted ranks, mainly in the Danish Army. I examine warriorisation 
among the professional Danish combat troops with whom I have conducted fieldwork as an "embedded anthropologist" before, during and after deployment to Helmand, Afghanistan (Pedersen, 2017b; 2019b) and later to Anbar, Iraq. ${ }^{2}$ Furthermore, I explore warriorisation within a number of civilian and military spheres beyond the ranks of my informants, although my informants arguably remain entangled in these spheres to varying degrees. Specifically, this chapter juxtaposes fragments from ethnographic fieldwork with tankers, infantry- and recce men and from my textual analyses of discursive material produced by Danish Defence institutions, military scholars, organisations supporting Danish veterans ${ }^{3}$ and public culture outlets. The chapter moves in and out of montage components, comprising interview snippets, news articles, blogs, dictionary entries, fieldnotes, research outputs, films, TV series, organisation websites and social media posts, all combined with my own analytical reflections, in an attempt to sketch and make sense of the multifarious faces of the warrior. In what follows, the montage specifically juxtaposes eight thematically compounded "warrior faces," gradually shifting its emphasis from contexts to texts, from discursive material to fieldwork data.

\section{Warrior Face \#1: the War-Fighter}

Deriving etymologically from the German Krieger, the Danish kriger (i.e., warrior) is defined in The Danish Dictionary (DSL, 2021) both as a "person who fights or will fight in a war - in particular related to historical or foreign affairs" and as a "(modern) soldier." According to the dictionary, the latter definition is often used humorously. If we stick to the first definition of warrior as "war-fighter," it strongly resonates with the fact that the momentum of the current warriorisation of military professions in Denmark has, up to a point at least, coincided with the increased militarisation of Denmark's foreign policy activism in the post-9/11 years (see also Holsting, this volume). After the mass slaughters in the First World

2 This chapter draws upon my ethnographic fieldwork with Danish contingents in the International Security Assistance Force (ISAF) and in Operation Inherent Resolve (OIR). The ISAF fieldwork forms part of my doctoral studies on soldierly becomings, while the OIR fieldwork is part of my current research on vicarious warriorhood. The ISAF fieldwork had a duration of one year, including three field trips to Camp Bastion, Helmand, involving forty principal informants. The OIR fieldwork has so far lasted two and half month, including two field trips to Al Asad Air Base, Anbar, involving twenty principal informants. The field research was designed as multi-sited and multi-periodical, involving

3 In Denmark, a "veteran" is officially defined as a person who has been deployed to an international operation at least once (Danish MoD, 2016). participant-observation, visual methods and qualitative interviews. 
War, any traditional notion of the warrior as a figure associated with glory and heroism (Coker, 2007) was largely consigned to the dustbin of history across Europe (Howard, 2009; Henningsen, 2019). In the case of Denmark, however, the figure of the warrior has gradually been revived alongside Denmark's military engagements in the American-led wars in Afghanistan and Iraq. In particular, the deployment of Danish troops to southern Afghanistan's Helmand province (2006-2014) seems to have catalysed a rise in warriorisation. After all, the deployment of Danish troops to Helmand in a war-fighting role and their frequent participation in regular combat were without precedent in the post-1864 era.

Consequently, contrary to The Danish Dictionary, the newly reinvigorated term "warrior" is frequently used in dead earnest, reflecting the increased seriousness of Danish soldiering in the early 21 st century (see also Høiback; Roelsgaard Obling, both this volume). As testified by the Monument to Denmark's International Efforts since 1948, among the 111 Danish personnel who did not return alive from more than 20 different missions, 8 lost their lives in Iraq and 44 in Afghanistan. Indeed, among the forty-nine Danish soldiers "killed in action" since 1992, six were deployed to Iraq and thirty-seven to Afghanistan. In comparison, Denmark's military engagement in Afghanistan has potentially resulted in the killing of more than 1,000 "Taliban fighters" and other "insurgents" (Thomsen \& Svendsen, 2013). No wonder, then, that it was during the heyday of the Danish Helmand campaign that the growing warriorisation began to disclose itself. "Warrior," I suggest, fulfilled the need for a new notion, a new identity, however archaic or outlandish, to distinguish the new breed of offensive Danish troops from their predominantly defensive predecessors of the past 150 years, whether these antecedents had been the defenders of national territory or international peacekeepers.

\section{Warrior Face \#2: the Distant Other}

Warrior: "person who fights or will fight in a war - in particular related to historical or foreign affairs" (DSL, 2021; my emphasis). While the first part of The Danish Dictionary's definition can apply to those outside the military professions, the second part implies a casting of "the warrior" as a distant Other in time and space - a Spartan or a samurai, for example. Significantly, in terms of historical affairs, the current warriorisation of military professions in Denmark is not unprecedented. As indicated by war memorials and "warrior graves" (knigergrave), particularly in the southern part of Denmark, Danish soldiers killed or fatally wounded on the battlefields of the two Schleswig Wars were occasionally commemorated by posterity and among their contemporaries as warriors. This was especially so in the case of the victorious war of 1848-1850, while the popularisation of the warrior 
was apparently much less pronounced in the case of the disastrous war of 1864 (Cohen, 1851; Cohen, 1865; Boeck, 1940). This past warriorisation, I suggest, was intimately tied to the current of romantic nationalism in Europe at the time, which in Denmark and elsewhere tapped into the Nordic revival (Wawn, 2000; Adriansen, 2003; Glenthøj, 2012). This revival, which has continued without interruption until today, has often entailed simplifying representations of Vikings as adventurous explorers, heroic defenders of the realm or noble savages (Wawn, 2000; Adriansen, 2003; Dyvik, 2016). Such romantic Viking imaginaries among "our troops" can be traced back to Denmark-Norway's involvement in the Napoleonic Wars (Glenthøj, 2012), and today warlike Viking imageries are very much back in fashion in the Danish Army (Pedersen, 2017b; Frisk, 2019; Lund, 2020).

As for foreign affairs, the names applied to the present-day enemies of Denmark and its allies are worth noting: "Islamic State fighters" (IS-krigere), "Taliban fighters" (Taleban-krigere) and "foreign fighters" (fremmedkrigere). In Danish, these enemies are referred to as "warriors" (krigere), not "fighters" (kempere). These enemies, or "adversaries" in modern army lingo, are not organised into internationally recognised state forces, and the Danish warrior rhetoric on these "enemies of the state" seems to be drawing on a Eurocentric, Clausewitzian notion of the "warrior spirit" (Clausewitz, 2007, 145): that is, a term above all applicable to primitivised, racialised, or, as I would add, tribalised or ethnicised people in the colony and post-colony, such as Maori-krigere or Mujahideen-krigere. Thus, contrary to the Clausewitzian "warrior spirit" that creates an "abnormal" distance between self and other, the revival of Danish warriorhood, I suggest, actually narrows the gap between self and other, both at the discursive and at the organisational level. As for the latter, numerous European militaries in the post-Cold War era, including the Danish, have adapted to "wars of choice" rather than "wars of necessity" (Haass, 2009). Armed forces throughout Europe have transitioned from geographically dispersed national organisations with lower ranks of mostly conscripted citizen soldiers to downsized organisations with practically every echelon staffed by volunteers and increasing numbers of professional troops (King, 2011), thereby arguably widening the gap between civilian and military communities (Ricks, 1997; Coker, 2007). This professionalisation of militaries in Europe and beyond has even been described as a process by which "our troops" enter a "warrior caste" (Schafer, 2017) or a "warrior class" (Coker, 2007; Angry Staff Officer, 2016) of their own. Thus conceived, "our troops" may arguably form an exceptionalist "warrior elite" (Huntington, 1957; see also Brænder; Ydén, both this volume), assumingly resonating with the social organisation of distant "warrior societies," be that in Ancient Greece, or in the colonies and post-colonies of European empires.

In the case of Afghanistan, the discursive level, for its part, has involved a 
mirroring process through which Danish forces who fought against "Taleban-krigere" arguably became "warriors" themselves, thereby, put somewhat provocatively, disregarding Nietzsche's famous warning "Anyone who fights with monsters should take care that he in the process does not become a monster" (Nietzsche 1998, p.68). After all, warriorisation, it seems, may harbour a monstrous journey into the abysmal "heart of darkness" (Conrad, 2002). This appears, for instance, to be the case when the Inspector-General of the Australian Defence Force invoked a notion of "warrior culture" as the explanation for possible war crimes committed by members of the Australian Special Air Service Regiment during the war in Afghanistan (Svendsen, 2020). In the Danish case, I would contend that warriorisation of both the Taleban and the Danish forces involves a discursive levelling of the playing-field and stresses the mirroring of "our" and "their" respective fighting capacities, as if the war in Afghanistan were fought between equal combatants in a symmetrical conflict. In conceiving "our adversaries" and "our troops" as "warriors," we de-contextualise the war politically and socio-economically, placing the Taliban and the Danes on the same level, morally speaking, insofar as "both parties" embody the "warrior spirit" and thus arguably subscribe to a common "warrior ethos" (Coker, 2007).

\section{Warrior Face \#3: the (Army) Officer}

In 1988, Sørensen published The Danish Officer: From Warrior to Administrator, arguing that the professional identity of the Danish officer after the Second World War had shifted from warrior to administrator as a result of the growing civilianisation and demilitarisation of the officer profession in Denmark and elsewhere in "the West" (see also Berndtsson; Victor Tillberg; Ydén; all this volume). The Cold War officer had become a "desk warrior" at best. All the same, Sørensen's portrait of the officer profession was soon to be challenged by the fall of the Berlin Wall and Denmark's subsequent military activism, which has involved the deployment of Danish troops to a large number of international operations throughout the world.

The figure of the warrior was initially revived within the ranks of the Danish officer corps in the mid-1990s, following the end of the Cold War. At that time the slogan "warrior, diplomat and corporate manager" ("kriger, diplomat og virksomhedsleder") started to gain ground at the Royal Danish Military Academy (Clemmesen, 2020). In other words, back in the 1990s, the institutional subject formation of Danish (army) officers began to encapsulate the "officer profile" (Vejre, 2002) by which the ideal officer must be able to master the professional identities of "the warrior," "the diplomat" and "the corporate manager." Indeed, as evidenced by an officer recruitment event at the Royal Danish Defence College 
as late as 2019, this officer profile is still in use as a description of the identities into which one moulds cadets enrolled in the College's Diploma Programmes in Military Studies (Rasmussen, 2019). Importantly, the officer profile arguably claims that the officer profession has a monopoly on the warrior identity in terms of the expertise and the corporateness acquired through the education and training offered by the military, naval, and air force academies (see also Nørgaard, Thorbjørnsen \& Holsting, 2008; Nørgaard, 2010; Danielsen, 2018).

Throughout the years, the officer profile has been both celebrated (Vejre, 2002; Møller, 2005; Helsø, 2010) and contested among officers and military scholars (Clemmesen, 2009; Sjøgren, 2012; Nyemann \& Staun, 2020). Colonel Lars R. Møller (2004), for instance, has disagreed with what he perceived to be the distribution of the three identities particularly at the higher echelons of the Danish Armed Forces: 10\% "warrior," 30\% "diplomat," and 60\% "corporate manager." Advocating more warriorisation, Møller insisted that the Danish Armed Forces should not be "a coffee club of administrators and paper-pushing bureaucrats but an organisation whose ultimate purpose is to direct a good deal of destructive violence to where there is need for it." He then arguably invokes "the warrior" as the raison d'être of the military, as a claim to professional autonomy, and as an identity-marker distinguishing the officer profession from civilian occupations, thereby "pushing back" against the civilianisation and demilitarisation of the officer corps (see also Brænder, this volume).

Perhaps unsurprisingly, "the administrator" was apparently stowed away during the officer recruitment campaign targeting Danish high-school students between 2008 and 2012 -at the height, that is, of the Danish Helmand campaign. The recruitment campaign was tailor-made for each of the three branches of the Danish Armed Forces. Interestingly, while the sub-campaigns for the Navy and for the Air Force were designated "Sea Student" (Stud Sø) and "Air Student" (Stud Luft), respectively, the sub-campaign for the Army did not go by the name of "Land Student" (Stud Land) but, rather, the somewhat sexier title "Warrior Student" (Stud Kriger). In that sense, the Army campaign was monopolising "warrior" as an identity that applied only to the Army's officer corps. What is more, Warrior Student neatly captures the field of tension inherent in the demand for contemporary officers to possess both military and academic competencies. "Warrior first, academic second," as it was phrased in the Danish Defence news in the face of the restructured officer educations in 2008 (Lærkholm-Bengtsen, 2008). In this context, "warrior" is invoked to make a claim to professional autonomy, pushing back specifically against a growing academisation of the officer corps, which has sparked concern, perhaps even an identity crisis, over the future of the officer profession (Kaplers, 2012; Brøndum, 2017; see also Berndtsson, this volume). 


\section{Warrior Face \#4: the Veteran}

The passage from military to civilian life on returning from deployment in the warzone is often difficult, and in 2008 the Danish Institute for Military Psychology launched the Acclimatisation and Reintegration (A\&R) Programme to ease the transition. Emphasising recovery, stress reduction, social interaction and job search skills, the programme, lasting three months, aimed to prevent psychological after-reactions by supporting the transition from "battle-mind" to "home-mind" (Jonasen, 2009) - or "from warrior to civilian," as it was put in the Danish Defence (2008) news. Here, one becomes a "warrior" through transformative war experiences altering one's state of mind. "The warrior" is a veteran with a hyper-vigilant and adrenaline-craving "battle-mind," and the A\&R Programme seeks to "de-warriorise" veterans to ease their way back into civilian contexts in which the warrior would be inappropriate, potentially unhealthy, even dangerous, to set free.

Today, depictions of "battle-minded" veterans living in the midst of "home-minded" civilians have naturally found their way into Danish popular culture. Take, for instance, Christopher Boe's 2018 crime drama, the TV mini-series Warrior. CC, the principal male character, is a hard-hitting veteran with years of experience in warzones across the world. He leaves the military only to embody the slogan "once a warrior, always a warrior" as he gets caught up in conflicting loyalties between law-enforcing police and law-breaking bikers. As such, "the warrior" is represented as a violent and morally ambiguous character. By comparison, Janus Metz's box-office hit of 2010, the war documentary Armadillo, portrays transformations of inexperienced soldiers into combat-proven veterans. In 2011, Armadillo won the Bodil Award in the Best Documentary category. Reflecting the strong debate Armadillo had provoked in the Danish public at its opening the previous year, the Award Committee (2011) stated the film was
an extremely sober-minded documentary on young Danish men that slowly but surely, on the often-meaningless patrols in Afghan- istan's Helmand province, become warriors, and perhaps, perhaps not, liquidate injured Taliban fighters. Armadillo is ... an inescapable testimony to Denmark's national loss of innocence.

Again, "the warrior" is a morally dubious, dark-hearted figure that one may come to embody through one's subjectifying experiences with brutal and brutalising acts of combat - acts through which the innocence of youth is lost, and the innocence of a nation, which for decades had grown accustomed to regarding itself as peaceful, along with it (Daugbjerg \& Sørensen, 2017). Regardless 
of what we make of Armadillo, the documentary draws a portrait of what has become known as Denmark's new "warrior generation" (krigergeneration). This notion is occasionally used in the Danish public by the media, military officers, and military scholars, myself included (Sørensen, 2017; Pedersen, 2017b). The notion applies to Danish forces who served in the bloody wars in Afghanistan and Iraq. The "warrior" of the "warrior generation" is a claim to generational corporateness, a claim to a generational identity ascribed to veterans by virtue of their subjectivity-formatting deployment to warzones where "our troops" were regularly engaged in regular combat. Consequently, this warrior generation excludes other generations such as the current post-Helmand generation, the older Balkan generation, let alone the still-older Cold War generation. Affiliation to the warrior generation is not merely to be set apart from other soldiers and veterans. Insofar as war and combat experiences constitute a yardstick for military expertise, not to mention for military adventures and military masculinities (Dawson, 1994), the notion of the warrior generation is implicitly hierarchising the different generations, placing Afghanistan and Iraq veterans at the top of the professional, masculinised value hierarchy (see also Roelsgaard Obling; Sløk-Andersen \& Persson, both this volume). As indicated by my research with Danish OIR troops, this internal ranking might help explain why the current post-Helmand warriorisation not merely lingers on but might even be growing across both the "warrior generation" and the "post-Helmand generation." To be sure, while this is not the case for all Danish army units, not even for the fighting arms (Bangsgaard \& Lintrup 2020), it is definitely so for some (Jacobsen, 2020; Lund, 2020).

\section{Warrior Face \#5: the Specialist, the Exerciser, and the Lifestyler}

In recent years, the notion of the warrior has enjoyed a resurgence in relation to vocations, or specialisations, across both civilian and military spheres in Denmark and elsewhere (Ricks, 2016). In civilian contexts, we may encounter "internet warriors" (internetkrigere), "culture warriors" (verdiknigere) or "soccer warriors" (fodboldkrigere), among others. Here, "warrior" constitutes an identity associated with dedication, persistence, advocacy, and aggression. In military contexts, on the other hand, we may, for instance, come across "information warriors" (informationskrigere), "drone warriors" (dronekrigere) or "cyber warriors" (cyberknigere). In this respect, the status of warrior is ascribed to military specialists in the non-fighting arms regardless of specialities and implied expertise. As such, "warrior," I suggest, entails a claim to military kinship, a shared identity, an inclusive corporateness, applying to all service-members across both specialisations and arms (see also Loeb, 2003).

In 1990 a Danish mobilisation exercise was given the rather odd title Gev 
kriger - Valiant Warrior (Kandborg, 1991). More recently, Danish forces have recurrently taken part in one of Europe's largest military exercises, the British-led Joint Warrior. The biannual, multinational exercise is the successor to the Joint Maritime Course dating back to the 1950s, renamed Neptune Warrior in 2006 before arriving at its present title in 2008 (Royal Navy, 2016). It is important to note, first, that the warriorisation of the Joint Maritime Course coincided with the growing revival of Danish warriorhood. Second, the "warrior" in both Joint Warrior and Valiant Warrior makes a claim to corporateness based on participation in the respective exercise. As such, it excludes non-participants from the "warrior community" of the given exercise. As far as the exercisers are concerned, however, "the warrior" is inclusive across ranks, functions, arms and, in the case of Joint Warrior, across branches and nationalities, too.

An even more inclusive claim to corporateness is found in public culture related to Denmark's recent military engagements. In 2009, the title of the Danish Armed Forces' in-house magazine Krigeren ("the warrior"), unpublished for years, was adopted by the private internet media Krigeren.dk (2019a). Covering news on Danish defence-related subjects, Krigeren.dk (2019b) has as its stated aim the development of a website in close rapport with current and former servicemembers, military families, and others with an interest in a military lifestyle. In Krigeren.dk's webstore, one can buy t-shirts with "Kriger" printed on the front. The product description runs as follows: "The t-shirt for veterans, infantrymen, patrol warriors, sandbox warriors, Home Guard warriors, office warriors, everyday warriors, kitchen warriors, air force warriors, naval warriors, YMCA warriors, KFOR warriors ... [insert word] warriors ... 100 percent cotton! 100 percent Warrior!" (Krigeren.dk, 2021). In this context, "warriors", it seems, are those who identify as such and therefore fashion themselves with the Kriger t-shirt. Using the notion of warrior to grant access to a military lifestyle, Krigeren.dk democratises the "warrior community" and makes an effort at levelling out differences between different arms and different branches, between "grunts" and "POGs," and even between civilians and military personnel.

\section{Warrior Face \#6: the Passionate and the Tough}

"The war machines - for them things couldn't get wild enough. They were the ones who took pleasure in fighting." So said Sergeant First Class (1st Sgt) Friis,

4 "Grunt" (fodtudse): American slang for infantryman or low-ranking personnel in the fighting arms. "POG": a shorthand for "person other than grunt." 
one of my ISAF informants, when I conducted a follow-up interview in 2020, some years after he had left the military. Friis seemed to utter his statement with equal parts awe and disbelief. The words concerned those few men that Friis regarded to be "true warriors" (rigtige krigere) within the ranks of the Guard Hussar Regiment's 1st Light Recce Squadron, with whom Friis was deployed to the Siege of Musa Qala in 2006. Hence, "the warrior," for Friis, is one who shows a liking for war, one who has a passion for fighting (see also Coker, 2007), one who enjoys the adrenaline rush of combat (see also Brænder, 2016). By comparison, Sgt Andersen deployed to Helmand with the 1st Light Recce Squadron when ISAF's mission was drawing to its close in 2014. Unlike Friis, Andersen was never in combat during his tour, and warfighting is absent from the account of the differences between "soldier" and "warrior" that he gave me a few years back:

\begin{abstract}
Join the Army and by definition one becomes a soldier ... but not all soldiers become warriors, not even all combat soldiers. ... A soldier is an occupation ... the warrior is not ... to be a warrior is to have a specific mindset. You'll always seek to optimise yourself to be able of performing your best. ... To be a warrior one must go the extra mile ... one must be ready. ... A warrior performs soldiering with dedication, with fighting spirit, and aggression. Soldiering is all the warrior lives for.
\end{abstract}

Andersen, we can say, speaks of the warrior as something one becomes by virtue of possessing both a self-optimising mindset and a passion for soldiering (see also Coker, 2007). As such, Andersen's emic understanding of the term partly resonates with the etic notion of warrior that has emerged within military psychology over the past decade - a conception denoting the specific condition of mental toughness. In step with the increasing numbers of veterans struggling with mental health issues, a quest for "the mentally resilient warrior" (Svendsen, 2016) has surfaced: there is, in other words, a growing interest in developing trauma prevention measures in the United States and elsewhere, Denmark included (Defence Command Denmark [DCD] 2014; Hertz, 2015). In fact, striking a responsive chord with the conceptualisation of a "warrior ethos" (Coker, 2007) or a "warrior code" (French, 2017) as a value-based "mental shield" protecting "our troops" against moral injury (W. G., 2020), there are, in a Danish context, those who seem to have found a prescription for "mental resilience" (Møller, 2018) or "mental fitness" (Wenøe \& Schwensen, 2020).

Take Lars Møller, a former operator in the Jaeger Corps, a Danish special operations force, as an example. In 2018, Møller published Think Like a Warrior: 
Your Path to Mental Resilience, a self-help book based on his experiences as an operator, offering advice, hands-on tools, and self-developing assignments on coping with stress and mental challenges. In this context, "warrior" serves as an identity-marker of a mindset that one can achieve through self-development based on "mental resilience" training. One's warrior is a mental resource to be found within oneself - one has, so to speak, to find one's "inner warrior" to be mentally resilient in the face of the outer world. This "mental warrior" entails a claim to corporateness celebrating the resourceful, strong individual, while de-warriorising those who fail to become mentally tough, perhaps even in spite of meditation, mindfulness and other "mental resilience" training.

\section{Warrior Face \#7: the Virtuous, the Dead, and the Wounded}

In 2016, Brigade General Hicks of the U.S. 438th Air Expeditionary Wing awarded the Danish Air Force Corporal Balking and his military working dog Obelix the title "Warriors of the Month." Obelix was honoured for having an extraordinary nose for security at Forward Operating Base Oqab in Kabul, while Balking was honoured for his outstanding capacity-building efforts (DCD, 2016). In a similar vein, the Reaction Force Company of the Royal Life Guards has recently introduced the "Warrior of the Class" (holdets kriger), a title awarded to the highest-achieving private in terms of professionalism, flexibility, cooperation, initiative and coping with stress (Jacobsen, 2020). The "warrior" in the Warrior of the Month and in the Warrior of the Class is an honour bestowed on one from above on the account of one's exceptional achievements on the ground. A warrior is so designated to serve as an example for others, constituting an ascribed identity-marker of professional status based on virtuous actions. Elaborating on the connection between professionalism and warriorhood, 1st Sgt Friis states:

When one has been blown up a few times, and when one has experienced combat, the warrior becomes one who guards professional integrity ... We had this commander [who had] reflected upon a word that should define us, and he told us it should be "professionalism" because, as he said, "most people are well aware when they are professional." I embraced that somehow. It's about doing the right thing. And when no one is looking, too.

This brings us to my anthropological conceptualisation of the warrior. In my research on soldierly becomings (Pedersen, 2017b; 2019a), I conceive what I call the "virtuous warrior" to be an ideal of virtuous self-becoming - an ideal pursued 
through one's cultivation of "warrior virtues" such as courage, toughness, and, with Friis in mind, moral integrity (see also Coker, 2007). The "virtuous warrior" entails a self-fashioning struggle for identity embodying virtuous action, be that in the battlespace or on the training ground. However, given that virtuousness is formed in the struggle against our vices, that is, against the excesses and deficiencies of our actions, the "virtuous warrior" contends with constant challenges. This inherent ambiguity of virtue might help explain why we, at least in a Danish context, rarely hear anyone publicly declaring themselves to be a warrior in earnest. As Sgt Andersen stresses, "'warrior' is usually not a word one would go about and use about oneself ... It's a term that you may use about others. For instance, you might say, 'he is a great warrior [stor kriger]' or 'he is a true warrior' [rigtig kriger]. In any event, one has to prove that one is a warrior." Hence, following Andersen, and in accordance with the Warrior of the Month and the Warrior of the Class, we can say that "the warrior" is one recognised as such in the eye of the beholder. "Warrior" is a title one must earn. It is a badge of honour recognising one's extraordinary efforts; one's virtuous actions.

The notion of warrior may also be used to express one's last respects. Thus, Danish troops "killed in action", in accidents, or by their own hand, are occasionally commemorated as warriors by their commanders or by their fellow soldiers. On such occasions, commemorative words in the news, at memorial ceremonies, or at online memorials include phrases such as "All honour to your memory, warrior" (Toft, 2010) and "Thank you for everything, warrior" (Sundsdal, 2013), while Facebook comments bid farewell to the departed with words such as "Rest in peace, warrior" and "See you in Valhalla, warrior." Here, one becomes a "warrior" by virtue of one's violent, war-related death (see also Sørensen, 2017); "warrior" makes up an ascribed identity honouring Danish veterans who lost their lives to war or to its after-effects. "Warrior" tends to be used not merely to show respect for those of "our troops" who paid the "ultimate price," but also to evoke national romantic associations, be that of Viking warriors (vikingekrigere) who died in battle (einherjars) or that of fallen warriors (faldne krigere) in the two Schleswig Wars (see also Pedersen 2017b).

To be sure, one may certainly qualify for warriorhood on the grounds of one's war injuries, too. In step with Denmark's military engagements in Afghanistan and Iraq, several organisations have emerged offering support to the growing population of Danish veterans and their families. Most of these organisations have names in which "veterans" or "soldiers" form an integral part. Two, Danish Wounded Warriors (DWW) and the Danish Wounded Warrior Project (DWWP), stand out by drawing upon the deep-rooted trope of den sairede kriger: the wounded warrior (see, for example, Baumann, 1865). The DWWP was established by the 
Royal Danish Ballet Foundation in 2010. It is a non-profit organisation, which uses Pilates training to help wounded veterans and other survivors of multiple traumas regain a meaningful life (DWWP, 2021). By comparison, the DWW (Veteranskytterne) is a gun club, established in 2014, dedicated to veterans "wounded in action" and their families. The aim of the club is to use shooting and other therapeutic and recreational activities to recover the identity that many injured veterans have lost with their limbs or their military jobs (DWW, 2021). In the case of both DWW and DWWP, "our troops" become "warriors" by virtue of their war injuries, physical and psychological alike. In this sense, "warrior" implies a claim to corporateness based on shared suffering. "Warrior" works as an identity-marker of survival and sacrifice, invoking notions of moral and emotional worth (see Coker, 2007). Importantly, the status of warrior forms a bulwark against the victimisation to which Danish veterans have widely been subjected in public discourse. "Warrior" reclaims a sense not only of military masculinity, but also of "existential potency," the power of being able to affect the world and reclaim a sense of presence and significance (Pedersen, 2020; see also Jackson, 2013).

\section{Warrior Face \#8: the Brutal, the Brave and the Badass}

The Angry Staff Officer (2016), an American military blog, argues that warriors are brutal, undisciplined, and chaotic, fighting mainly for their own glory, while soldiers, in contrast, are "disciplined masters of warfare, acting out of a sense of duty and devotion to their homeland, families, or an ideal." In essence, soldiers are the very antithesis of warriors if we are to concur with the Angry Staff Officer, as 1st Sgt Friis does to a certain extent when he reflects upon what it means to be a warrior in the Danish Army: "In the beginning, before you're actually a warrior, you'll have an idea of what a warrior is. It can be produced by brilliant models in both films and computer games, or by some other gung-ho thing." Here, frenzy and recklessness constitute the defining features of warriorhood.

Moreover, the Danish ISAF troops I have followed did at large not deploy to Helmand out of any sense of duty and devotion to either the Danes or the Afghans; at least, there was something else that counted a lot more. As Frederiksen, a first lieutenant back then, bluntly put it shortly prior to his deployment to Helmand: "I don't care about the Afghans. That's not why we're there [in Afghanistan]. We're there to fight a war. Next time, the war is somewhere else, and then we go there as well." The ISAF tour was, in a nutshell, about the search for adventure, for action and, ultimately, for combat (Pedersen, 2017a; 2017b; 2019a; 2019c). It was, that is, a search traditionally associated with masculinity (Dawson, 1994; King 2013).

This search, I argue, forming a quest for self-becoming, both as "true warrior" 
and as "authentic individual," is, thereby, a search for glory in terms of being recognised for one's "warriorhood" and "authentic being" (Pedersen, 2017a; 2017b; see also Coker, 2007). Consequently, many of my informants returned from a relatively uneventful tour of duty with what I call "warrior bodies," "warrior looks," and "warrior images," which apparently served as self-fashioning substitutes for the ultimate but virtually absent "warrior formative" experience of combat.

For its part, the "warrior body" is the result of keeping fit and killing time during deployment with hour upon hour of bodywork going into growing muscles and sculpting oneself in the image of a "Greek god body" (Pedersen, 2017a; 2017b). The para-militarised "warrior look," on the other hand, is cultivated in particular with the image of battle-seasoned special operations force (SOF) operators, or private security contractors, in mind. It is fashioned through purchasing and wearing non-issued military gear such as 5.11 Tactical flagbearer caps, Mil-Tec shemagh scarfs, Crye Precision combat pants, Salomon light assault boots and specialised Tasmanian Tiger pouches (see also Noordally, 2020). As for the "warrior images," these are pictures taken of one posing in macho, bravado style with, say, raised assault rifles, or in front of a fully armed Apache Attack Helicopter, while looking very serious. In all three cases, "the warrior," I contend, is a tacit performance of identity, harbouring a masculinised claim to badassery, to violent potentiality, and thus to existential potency. Such performance of warriorhood may, however, tie into the pursuit of "toxic masculinities," as 1st Sgt Friis seems to indicate:

There are many wannabe warriors who'll think that being a warrior is all about being good at getting plastered ... going out beating people up. You see, that's also a way to climb up the hierarchies ... it may also just be about wearing a pair of cool shoes or deadlifting $250 \mathrm{~kg}$.

By the same token, warriorhood may be used as a measure for guarding access to the centre of military professions. And not least as far as women in the fighting arms are concerned (see also Sløk-Andersen \& Persson, this volume). As Private Roskilde confided to me in Camp Bastion, Helmand, in relation to one of her female fellow soldiers within the enlisted ranks of the Danish ISAF force: "The boys are asking her all the time: 'Why have you become a soldier? You're not enough of a warrior for that at all. You're too sweet'."

\section{Conclusion}

Addressing the incipient warriorisation of military professions in post-9/11 Denmark, this chapter has examined military professions and civil-military relations 
through an anthropological analysis of the cultural figure of the warrior. In an attempt to draw a multi-perspectival and multifaceted portrait of "the warrior," I have applied montage as a technique of ethnographic writing. Accordingly, I have presented my empirical material and my analytical reflections in a relatively fragmentary, non-linear fashion with a view to amplifying the invisible in terms of making contradictory and conflicting "gaps" visible between different faces of the warrior. Conceptualising "the warrior" as a question of professional identities, be that in terms of subject formation or self-fashioning, a complex and contested figure, with multiple contextual and situational (and occasionally overlapping) faces, emerges from the montage's juxtapositions. In this light, "warrior," I maintain, is a slippery term that must be applied with caution. The notion of warrior demands close and careful attention to its usage in words and deeds, be that by oneself or by others, whether as an emic or etic term, or somewhere in between. "Warrior" is a morally, emotionally, and masculinity-laden notion, opening gaps, or fields of tension, between inclusion and exclusion along lines, such as virtuousness and wickedness, heroism and villainism, sacrifice and self-centredness, bravery and brutality, passion and frenzy, education and experience, competency and potency. In short, insofar as warriors are wanted, the crucial question to ask is not so much "What's your warrior?" as "How are you a warrior?"

Whose club are you serving? That of "the pack," or that of "the people"?

\section{Acknowledgments}

I want to thank the editors Lotta Victor Tillberg and Anne Roelsgaard Obling, and my informants Cpt Frederiksen and 1st Sgt Friis, for valuable, helpful comments on earlier versions of this chapter. I also wish to thank Steffen Lind Christensen, Michael Hesselholt Clemmesen, Mads Daugbjerg, Rasmus Glenthøj, Karen Gram-Skjoldager, Jens Carl Kirchmeier-Andersen, René Rasmussen, Allan Slott Rasmussen, Karsten Merrald Sørensen, Jeppe Trautner, Lars Wille-Jørgensen, and Bjørn Østergaard for generous and insightful input.

\section{Funding}

This chapter is partially based on my ISAF fieldwork, which was made possible thanks to the support of my doctoral studies by the Independent Research Fund Denmark | Humanities (FKK) (grant no. 0602-02345B). 
Adriansen, I. (2003). Nationale symboler i det Danske Rige 1830-2000 (Vols. I-II) [National symbols in the Danish Realm 1830-2000]. Copenhagen: Museum Tusculanums Forlag.

Angry Staff Officer (2016, December 14). Stop calling us warriors. The Angry Staff Officer. Retrieved from: https://angrystaffofficer.com/2016/12/14/stop-calling-us-warriors/?fbclid=IwAR34HSGxLTMB3o2YkAZeXINfK5M4xU-5ysgIB4j2fpu9AYv7hVHUTXB4-8w

Award Committee of the Bodil Awards (2011). Bedste dokumentarfilm-Armadillo [Best documentary - Armadillo]. Retrieved January 13, 2021, from http://www.bodilprisen.dk/aar-for-aar/201 1-2/

Bangsgaard, M. S., \& Lintrup, M. S. (2020). Ny situation, ny selvopfattelse: Delingsforerens ansvar i en brydningstid [A new situation, a new self-perception: The platoon commander's responsibility in a time of unrest and upheaval] (Diploma thesis, Royal Danish Military Academy, Frederiksberg).

Baumann, E. J. (1865). En såret dansk kriger [A Danish wounded warrior]. Retrieved January 13, 2021, from https://collection.smk.dk/\#/detail/KMS852

Beehner, L. (2019, December 16). What Donald Trump doesn't understand about the difference between soldiers and "warriors." USA Today. Retrieved from https://eu.usatoday.com/story/ opinion/2019/11/27/edward-gallagher-donald-trump-warriors-soldiers-war-crimes-column/4318452002/

Boe, C. (2018). Kriger [Warrior]. Copenhagen: Miso Film.

Boeck, H. (1940). Danske mindesmarker og krigergrave i Sonderjylland: Fra krigene 1813, 1848-50 og 1864 [Danish memorials and warrior graves in Southern Jutland: From the wars of 1813, 1848-50 and 1864]. Copenhagen: Slesvigsk Forlag.

Brænder, M. (2016). Adrenalin junkies: Why soldiers return from war wanting more. Armed Forces \& Society, 42(1), 3-25. DOI: https://doi.org/10.1177\%2F0095327X15569296

Brøndum, C. (2017). "Vi uddanner ikke akademikere. Vi uddanner officerer" [We do not produce academics. We train officers]. Fagbladet Officeren, 3, 31-33.

Clausewitz, C. v. (2007). On war (M. Howard \& P. Paret, trans.). Oxford: Oxford University Press (Original work published 1832).

Clemmesen, M. H. (2009, January 26). Om at glemme eller at skamme sig over at være militær [On forgetting or being ashamed of being military]. Det Krigsvidenskabelige Selskab. Retrieved from https://krigsvidenskab.dk/emne/om-glemme-eller-skamme-sig-over-vaere-militaer

Clemmesen, M. H. (2020). Personal communication [e-mail correspondence].

Cohen, A. D. (1851). Krigen i årene 1848, 1849, 1850 og de faldnes minde [The war in the years 1848, 1849, 1850 and the memory of the fallen]. Odense: M. C. Hempels Bogtrykkeri.

Cohen, V. (1865). Krigen $1864 \mathrm{og}$ de faldnes minde [The war of 1864 and the memory of the fallen]. Copenhagen: Gad.

Coker, C. (2007). The warrior ethos: Military culture and the war on terror. New York, NY: Routledge.

Conrad, J. (2002). Heart of darkness and other tales (Rev. Ed.). Oxford: Oxford University Press.

Cox, M. (2018, October 19). Army launches new "Warriors Wanted" campaign aimed at generation Z. Military.com. Retrieved from https://www.military.com/dodbuzz/2018/10/19/army-launches-new-warriors-wanted-campaign-aimed-generation-z.html

Danielsen, T. (2018). Making warriors in a global era: An ethnographic study of the Norwegian Naval Special Operations Commando. Lanham, MD: Lexington Books.

Danish Defence (2008, August 29). Når soldater bliver civil [When soldiers move back into civilian life]. Retrieved from https://www2.forsvaret.dk/nyheder/intops/Pages/N\%C3\%A5rsoldatenblivercivil.aspx

Danish Ministry of Defence (MoD) (2016). The veteran policy of Denmark. Retrieved January 13, 2021, from https://fmn.dk/globalassets/fmn/dokumenter/strategi/veteraner/-the-veteran-policy-of-denmark-2016-.pdf 


\section{References}

Danish Wounded Warriors (DWW) (2021). Vores mission [Our Mission]. Retrieved January 13, 2021, from https://veteranskytterne.dk/om-os

Danish Wounded Warrior Project (DWWP) (2021). About DWWP. Retrieved January 13, 2021, from http://danishwoundedwarriors.com/about-dwwp/

Daugbjerg, M., \& Sørensen, B. R. (2017). Becoming a warring nation: The Danish "military moment" and its repercussions. Critical Military Studies, 3(1), 1-6. DOI: https://doi.org/10.1080/233374 86.2016.1231994

Dawson, G. (1994). Soldier heroes: British adventure, empire and the imagining of masculinities. London: Routledge.

Defence Command Denmark (DCD) (2014). Forsvarets og Hjemmevarnets sundheds- og trivselsstrategi [Danish Defence and Danish Home Guard strategy for health and well-being]. Retrieved January 13, 2021, from https://medarbejder.forsvaret.dk/da/ansaettelsesforhold/administration/strategiog--politik/hr-delstrategi-7--sundheds--og-trivselsstrategien/

Defence Command Denmark (DCD) (2016, December 8). Dansk sprængstofshund er "månedens kriger" [Danish explosive detection dog is "warrior of the month"]. Retrieved from https://www2. forsvaret.dk/nyheder/intops/Pages/Danskspraengstofhundermaanedenskrigeraspx

DSL (Society for Danish Language and Literature) (2021). The Danish Dictionary: Modern Danish Language. Retrieved January 13, 2021, from https://ordnet.dk/ddo_en?set_language=en

Dyvik, S. L. (2016). "Valhalla rising": Gender, embodiment and experience in military memoirs. Security Dialogue, 47(2), 133-150. DOI: https://doi.org/10.1177\%2F0967010615615730

Foucault, M. (1977). Discipline and punish: The birth of the prison (A. Sheridan, Trans). London: Penguin.

French, S. E. (2017). The code of the warrior: Exploring warrior values past and present (2nd ed.). London: Rowman \& Littlefield.

Frisk, K. (2019). Armadillo and the Viking spirit: Military names and national myths in transnational military interventions. Critical Military Studies, 5(1), 21-39. DOI: https://doi.org/10.1080/233 37486.2017 .1319644

Gibson, J. W. (1994). Warrior dreams: Violence and manhood in post-Vietnam America. New York, NY: Hill and Wang.

Glenthøj, R. (2012). Skilsmissen: Dansk og norsk identitet for og efter 1814 [The divorce: Danish and Norwegian identity before and after 1814]. Odense: University Press of Southern Denmark.

Goffman, E. (1959). The presentation of self in everyday life. London: Penguin Books.

Haass, R. N. (2009). War of necessity, war of choice: A memoir of two Iraq wars. New York, NY: Simon and Schuster.

Helsø, H. J. (2010). Forord [Preface]. In L. U. Johannesen, De danske tigre: Med livet som indsats i Afghanistan [The Danish Tigers: In Afghanistan at the risk of one's life] (2nd ed.) (pp. 7-9). Copenhagen: Gyldendal.

Henningsen, L. N. (2019). Kampen om de faldnes minde: 100 års strid om mindesmarker og mindekultur $i$ Sønderiylland efter Forste Verdenskrig [The battle for the memory of the fallen: 100 years of dispute about memorials and memory culture in Southern Jutland after the First World War]. Aabenraa: Historisk Samfund for Sønderjylland.

Hertz, E. (2015). Mental roubusthedstræning i Livgarden - et interventionsstudie vedrørende kampsoldaters psykologiske velbefindende [Mental resilience training in the Royal Life Guards - an intervention study on the psychological well-being of combat soldiers]. Psyke \& Logos, 36, 219-237.

Howard, M. (2009). War in European history (Updated ed.). Oxford: Oxford University Press.

Huntington, S. P. (1957). The soldier and the state: The theory and politics of civil-military relations. Cambridge,

MA: Harvard University Press.

Jackson, M. D. (2013). The politics of storytelling: Variations on a theme by Hannah Arendt (2nd ed.). Copenhagen:

Museum Tusculanum Press. 
Jacobsen, E. L. (2020). Feg vil vaere kriger! Hvordan bliver den unge officer en kriger? [I want to be a warrior! How does the junior officer become a warrior?] (Diploma thesis, Royal Danish Military Academy, Frederiksberg).

Jenkins, R. (2014). Social identity (4th ed.). New York, NY: Routledge.

Jonasen, R. (2009). Fra "battlemind" til "homemind" [From "battlemind" to "homemind"]. Militert Tidsskrift, 138(1), 40-46.

Kandborg, O. (1991). Gæv kriger en god investering [Valiant Warrior, a good investment]. Militert Tidsskrift, 120(4), 130-139.

Kaplers, P. (2012, January 13). Med fokus på professionen - soldater eller akademikere? [Focussing on the profession - soldiers or academics?] Retrieved from Det Krigsvidenskabelige Selskab. https:// www.krigsvidenskab.dk/emne/med-fokus-pa-professionen-soldater-eller-akademikere

King, A. (2011). The transformation of Europe's armed forces: From the Rhine to Afghanistan. Cambridge: Cambridge University Press.

King, A. (2013). The combat soldier: Infantry tactics and cohesion in the twentieth and twenty-first centuries. Oxford: Oxford University Press.

Krigeren.dk (2019a). Om os [About us]. Retrieved November 5, 2019, from http://krigeren.dk/om-os/

Krigeren.dk (2019b). Mission. Retrieved November 5, 2019, from: https://www.facebook.com/pg/krigerendk/about/?ref=page_internal

Krigeren.dk (2021). Store. Retrieved January 13, 2021, from http://krigeren.dk/store/KRIGER-T-shirt*LARGE*-TILBUD-p39786536

Loeb, V. (2003, September 8). Army plans steps to heighten "warrior ethos." The Washington Post. Retrieved from https://www.washingtonpost.com/archive/politics/2003/09/08/army-planssteps-to-heighten-warrior-ethos/aafb2625-a33d-48ca-8fcf-3ef2747f1243/

Lund, A. K. (2020). Patchwork: At integrere enhedsmarker i narrativer og kultur [Patchwork: Integrating unit badges into narratives and culture]. (Diploma thesis, Royal Danish Military Academy, Frederiksberg).

Lærkholm-Bengtsen, L. (2008, May 8). Kort uddannelse skal give flere hænder [Short-cycle education is meant to result in more manpower]. Retrieved from https://www2.forsvaret.dk/nyheder/ overige_nyheder/Pages/Kortuddannelseskalgiveflereh\%C3\%A6nder.aspx

Marcus, G. E. (1990). The modernist sensibility in recent ethnographic writing and the cinematic metaphor of montage. SVA Review, 6(1), 2-12. DOI: https://doi.org/10.1525/var.1990.6.1.2

Matthew (2020, May 12). Wavell chats: Warrior ethos. Wavell Room. Retrieved from https://wavellroom. com/2020/05/12/wavell-chats-warrior-ethos/

Metz, J. (2010). Armadillo. Copenhagen: Fridthjof Film.

Møller, K. J. (2005). Forsvarsakademiet - viden og fremsyn gennem 175 år [The Royal Danish Defence College - knowledge and foresight through 175 years]. In M. H. Clemmesen \& P. K. Laustsen (Eds.), Festskrift - Forsvarsakademiet 175. arsdag [Commemorative publication - the 175 anniversary of the Royal Danish Defence College] (p. 3). Copenhagen: Forsvarsakademiet.

Møller, L. (2018). Tenk som en kriger: Din vej til mental robusthed [Think like a warrior: Your path to mental resilience]. Copenhagen: Storyhouse.

Møller, L. R. (2004, April 1). Er vi da bare de glade amatører? [Are we just the happy amateurs?]. Det krigsvidenskabelige selskab. Retrieved from https://www.krigsvidenskab.dk/emne/er-vi-da-barede-glade-amatorer

Nietzsche, F. (1998). Beyond good and evil (M. Faber, trans.). Oxford: Oxford University Press.

Noordally, R. (2020, April 28). On the toxicity of the "warrior" ethos. Wavell Room. Retrieved from https://wavellroom.com/2020/04/28/on-the-toxicity-of-the-warrior-ethos/

Nyemann, D. B., \& Staun, J. (2020). Denmark's strategic lieutenants. Parameters, 50(1), 91-103. 


\section{References}

Nørgaard, K. (2010). Den politiske kriger: Arbejdshefte til Militeretik og ledelse i praksis [The political warrior: Workbook for military ethics and leadership in practice]. Copenhagen: Forsvarsakademiet.

Nørgaard, K., Thorbjørnsen, S. R., \& Holsting, V. (2008). Militer etik og ledelse i praksis [Military ethics and leadership in practice]. Copenhagen: Forsvarsakademiet.

Pedersen, T. R. (2017a). Get real: Chasing Danish warrior dreams in the Afghan "sandbox." Critical Military Studies, 3(1), 7-26. DOI: https://doi.org/10.1080/23337486.2016.1231996

Pedersen, T. R. (2017b). Soldierly becomings: A grunt ethnography of Denmark's new "warrior generation.” (Doctoral dissertation, University of Copenhagen).

Pedersen, T. R. (2019a). Ambivalent anticipations: On soldierly becomings in the desert of the real. The Cambridge Fournal of Anthropology, 37(1), 77-92. DOI: https://doi.org/10.3167/ cja.2019.370107

Pedersen, T. R. (2019b). Breaking bad? Down and dirty with military anthropology. Ethnos (published ahead of print). DOI: https://doi.org/10.1080/00141844.2019.1687550

Pedersen, T. R. (2019c). The entangled soldier. On the messiness of war/law/morality. In B. R. Sørensen \& E. Ben-Ari (Eds.), Civil-military entanglements: Anthropological perspectives (pp. 164-184). Oxford: Berghahn.

Pedersen, T. R. (2020). "Democracy ... 120 mm at a time": Mission formations and operational entrapments in post-9/11 Afghanistan. In T. V. Brønd, U. Ben-Shalom \& E. Ben-Ari (Eds.), Mission formations and hybrid wars: New sociological perspectives (pp. 141-166). New York, NY: Routledge.

Rapport, N. (2003). I am dynamite: An alternative anthropology of power. London: Routledge.

Rasmussen, A. K. (2019). Officer i Forsvaret: Karrieredagene [Officer in the Danish Defence: The career days] (PowerPoint presentation). Retrieved January 13, 2021, from https://www.karrieredagene.dk/ wp-content/uploads/Forsvaret.pdf

Rempfer, K. (2019, October 16). "What's Your Warrior?” Army launches new adds with less combat focus. Army Times. Retrieved from https://www.armytimes.com/news/your-army/2019/10/16/whats-your-warrior-army-launches-new-ads-with-less-combat-focus/

Ricks, T. E. (1997, July). The widening gap between military and society. The Atlantic. Retrieved from https://www.theatlantic.com/magazine/archive/1997/07/the-widening-gap-between-military-and-society/306158/

Ricks, T. E. (2016, September 15). What's a soldier? What's a warrior? Well, do you want to live in a state or in a tribe? Foreign Policy. Retrieved from https://foreignpolicy.com/2016/09/15/whats-asoldier-whats-a-warrior-well-do-you-want-to-live-in-a-state-or-in-a-tribe/

Royal Navy (2016, October 7). Major military exercise comes to Scotland. Retrieved from https://www.royalnavy.mod.uk/news-and-latest-activity/news/2016/october/07/161007-major-military-exercise-comes-to-scotland

Schafer, A. (2017). Generations of war: Rise of the warrior caste and the all-volunteer force. Washington, DC: Centre for a New American Security.

Sjøgren, S. (2012). Med støvlerne på - i krig i Irak og Afghanistan [With one's boots on - at war in Iraq and Afghanistan]. Copenhagen: Gyldendal.

Sundsdal, C. (2013, December 14). Afsked med en god ven og kriger [Farewell to a good friend and warrior]. Krigeren.dk. Retrieved from http://krigeren.dk/afsked-med-en-god-ven-og-kriger/

Svendsen, J. (2016, September 5). Jagten på den robuste kriger [The hunt for the resilient warrior]. Politiken. Retrieved from https://politiken.dk/magasinet/feature/art5634699/Jagten-p $\% \mathrm{C} 3 \% \mathrm{~A} 5$-den-robuste-kriger

Svendsen, J. (2020, 6 December). Regler blev brudt, løgne fortalt, og fanger blev dræbt - 39 gange [Rules were broken, lies told and prisoners killed - 39 times]. Politiken. Retrieved from https:// politiken.dk/udland/art8019759/Regler-blev-brudt-1\%C3\%B8gne-fortalt-og-fanger-blevdr $\%$ C3 $\%$ A6bt- $\%$ E2\% $\% 0 \% 93$-39-gange 
Sørensen, B. R. (2017). Public commemorations of Danish soldiers: Monuments, memorials, and tombstones. Critical Military Studies, 3(1), 27-49. DOI: https://doi.org/10.1080/23337486.2016.1 1 84417

Sørensen, H. (1988). Den danske officer: Fra kriger til administrator: Et social og politisk portret af den militere profession $i$ Danmark [The Danish officer: From warrior to administrator: A social and political portrait of the military profession in Denmark]. Copenhagen: Nyt fra samfundsvidenskaberne.

Thomsen, C. B., \& Svendsen, J. (2013, July 21). Forsvaret nægter at afsløre hvor mange talebanere, danske soldater har dræbt [The Danish Defence refuses to reveal the number of Taliban fighters killed by Danish soldiers]. Politiken. Retrieved from https://politiken.dk/indland/ art5474179/Forsvaret-n \%C3\%A6gter-at-afs1 \%C3\%B8re-hvor-mange-talebanere-danske-soldater-har-dr $\% \mathrm{C} 3 \% \mathrm{~A} 6 \mathrm{bt}$

Toft, M. C. (2010). Jorgen Randrup: Kompagnichefen Michael C. Tofts mindeord [Jørgen Randrup: Commemorative words by Company Commander Michael C. Toft]. Retrieved January 13, 2021, from https://forsvaret.dk/da/organisation/haeren/denkongeligelivgarde/aeret-vaere-deresminde/joergen_randrup/

Vejre, C. (2002). Officersprofilen i rekrutterings- og fastholdelsesperspektiv [The officer profile in a recruitment and retention perspective]. Militert Tidsskrift, 131(2), 165-173.

W., G. (2020, May 5). The "warrior culture" is more than a badge. Wavell Room. Retrieved from https:// wavellroom.com/2020/05/05/the-warrior-culture-is-more-than-a-badge/

Wawn, A. (2000). The Vikings and the Victorians: Inventing the Old North in 19th century Britain. Suffolk: D. S. Brewer.

Wenøe, H., \& Schwensen, E. (2020). Mental fitness for warriors - bliv veredygtig [Mental fitness for warriors become better at being]. Holte: Acuity World Press.

West, C., \& Zimmerman, D. H. (1987). Doing gender. Gender \& Society, 1(2), 125-151. DOI: https://doi. org/10.1177\%2F0891243287001002002

Willerslev, R., \& Suhr, G. (2013). Introduction: Montage as an amplifier of invisibility. In C. Suhr \& R. Willerslev (Eds.), Transcultural montage (pp. 1-15). Oxford: Berghahn. 